\title{
Briquette: A New Horizon Towards the Alternative Fuel
}

\author{
Ronak Jakasania*, Rajvir Yadav and Ashwin Vadher \\ Department of Farm machinery and Power Engineering, Junagadh Agricultural University, India
}

Submission: June 22, 2018; Published: July 10, 2018

*Corresponding author: Ronak Jakasania, Department of Farm machinery and Power Engineering, College of Agricultural Engineering and Technology, Junagadh Agricultural University,Junagadh-362001, Gujarat, India, Email: ronakjakasania92@gmail.com

\section{Opinion}

As the world population increases there is an increase in the consumption of energy by high standard of living, energy demand also increases to fulfill it. The net energy demand could not be satisfied by the traditional efficient energy technology, which uses only a few local resources. All sectors of the Indian economy, such as agriculture, industry, transport and families need energy for the progress and prosperity of the nation and society. Energy is the cornerstone of economic and social development. As a result, energy consumption in all its forms has steadily increased worldwide.

Environmental protection and recycling of materials are important topics today. The increase in the cost of oil and the uncertainty of availability, realized worldwide, have necessitated the need to develop and use non-conventional energy sources, in particular solar and biomass energy. Much of the agricultural waste (biomass), especially weeds, herbs and other undesirable plants, is lost in one way or another, which can be a good source of fuel when used on a small scale.

Many developing countries produce huge amounts of agricultural residues, but they are used inefficiently, causing significant environmental pollution. Besides the problems of transport, storage and handling, the direct combustion of loose biomasses in conventional grates has been associated with low thermal efficiency and large atmospheric pollution. The conversion efficiencies were $40 \%$ with particulate emissions in the exhaust gases.

For effective utilization of biomass, briquetting technology is one of the convenient means. The development of a briquetting machine at a smaller scale can be used for making briquettes from the agricultural waste and can be used as fuel at rural level or at a small scale.

For the use of renewable energy sources, briquetting technology is used. Biomass fuels are used in many countries. Briquettes are produced not only from biomass, but also from different types of waste such as crushed paper, plastics, agricultural waste and other combustible waste. Different types of briquetting equipment and their modifications are under development. Alternative fuels like biomass are taking a step forward in the energy sector for green energy production. In many factories, they are used for gasification in power plants. Before briquetting, it is necessary to pre-condition the material. The first step is the treatment of waste by disintegrating the mills to reduce the size. A smaller particle size gives better product properties for drying, mixing and briquetting. Before briquetting, the moisture content of the material must be reduced by drying. A lower moisture content improves the briquetting process.

Briquetting is the technology of compaction of the most known. Briquetting consists in applying pressure to a mass of particles with or without binder and converting it into a compact aggregate. Because the biomass is compressed into a dense material, it is also called densification. Briquetting increases density with respect to free biomass material. Biomass briquettes are produced from agricultural waste, forest waste and industrial waste. It is converted into a cylindrical solid or any other desired shape by compression. The main residues used are: rice husk, coffee husk, coir pitch, jute sticks, sugarcane bagasse, groundnut shell, mustard stalks, cotton stalks, sawdust, caster seed shells/stalk, wood chips, bamboo dust, tobacco waste, tea waste, paddy straw, wheat straw, sunflower stalk, palm husk, soyabean husk, veneer residues, etc. The briquettes are only binders/densification, made from residues and having a high caloric power.

The technology uses the mechanical and chemical properties of the materials to compress them in a compact form (briquettes) without the use of additives or binders in the high pressure compaction process. Briquetting is mainly used for the compaction of biomass (sawdust, wood chips, bark, straw, cotton, paper, etc.). The biomass undergoes the briquetting process, while the high pressure and the temperature act simultaneously on the mass, the cellular structures in the lignin release 
material, which binds the individual particles in a briquette unit. For briquette quality control, physical parameters such as density, moisture content and compressive strength are the best indicators of briquette quality.

Many developing countries have diversified to promote this technology because it is low-polluting and easy to use. Even in India this is a product that is moving very fast, as state governments are encouraging this sector by providing incentives to producers, plant owners and briquettes users. Briquettes are widely used for steam production in boilers, heating, etc. As fuel, biomass/white coal tiles give better results. Currently in the Indian territory, it has used in industries such as paper mills, solvent extraction plants, vegetable factory, chemical plants, textile units, dye houses, food processing units, dairy plants, confectioneries, leather industries, etc. briquettes are very useful in all the sectors we need at all times. In our usual life, what we use is made using briquettes as fuel.

\section{Your next submission with Juniper Publishers will reach you the below assets}

- Quality Editorial service

- Swift Peer Review

- Reprints availability

- E-prints Service

- Manuscript Podcast for convenient understanding

- Global attainment for your research

- Manuscript accessibility in different formats ( Pdf, E-pub, Full Text, Audio)

- Unceasing customer service

Track the below URL for one-step submission https://juniperpublishers.com/online-submission.php 